\title{
PENGEMBANGAN PERANGKAT PEMBELAJARAN MATEMATIKA MENGGUNAKAN PEMBELAJARAN BERBASIS MASALAH UNTUK MEMFASILITASI PEMAHAMAN MATEMATIS PESERTA DIDIK
}

\author{
Pattimura SC ${ }^{1}$, Maimunah ${ }^{2}$, Nahor Murani Hutapea ${ }^{3}$ \\ ${ }^{1,2,3}$ Pendidikan Matematika, Universitas Riau, Pekanbaru, Indonesia \\ pattimura1964@gmail.com
}

\begin{abstract}
This Research is backed by a low understanding of students'mathematical skills and still many teachers experiencing difficulties in developing learning devices with learning models that are in line with the demands of the 2013 curriculum learning. The purpose of this research is to produce math learning tools using problembased learning to facilitate the ability to understand the mathematical skills of the students of The XI SMA class on the application material of the form of syllabus, RPP, LKPD, and test of mathematical ability which has valid and practical qualifications. This research is a development following the development model of 4D, but the research was limited to the developing stage. The research istrument used the device validation sheet and the student response poll. Development was conducted with a validation test against the device involving two experts and a practitioner through a validation assessment sheet and practicality test through limited trials involving 6 students through a student response poll. From the results of the analysis of the validation test data obtained average percentage score for: (1)syllabus 88.77\%; (2)RPP 90.60\%; (3)LKPD 91.98\%; (4)TKPM $94.89 \%$, each meeting the criteria is very valid. And practicality test data analysis results obtained average percentage score for student response of $87.46 \%$ with very practical criteria.
\end{abstract}

Keywords: Learning device, problem-based learning Model, mathematical understanding

\begin{abstract}
Abstrak
Penelitian ini dilatarbelakangi oleh rendahnya kemampuan pemahaman matematis peserta didik dan masih banyaknya guru yang mengalami kesulitan dalam mengembangkan perangkat pembelajaran dengan model pembelajaran yang sesuai dengan tuntutan pembelajaran kurikulum 2013. Tujuan penelitian ini untuk menghasilkan perangkat pembelajaran matematika menggunakan pembelajaran berbasis masalah untuk memfasilitasi kemampuan pemahaman matematis peserta didik kelas XI SMA pada materi aplikasi turunan berupa silabus, RPP, LKPD, dan tes kemampuan pemahaman matematis (TKPM) yang memiliki kualitifikasi valid dan praktis. Penelitian ini merupakan pengembangan dengan mengikuti model pengembangan 4D, namun pada penelitian dibatasi sampai tahap develop. Istrumen penelitian menggunakan lembar validasi perangkat dan angket respon peserta didik. Pengembangan dilakukan dengan Uji validasi terhadap perangkat (silabus, RPP, LKPD, TKPM) dengan melibatkan dua orang ahli dan seorang praktisi melalui lembar penilaian validasi dan uji kepraktisan melalui uji coba terbatas dengan melibatkan 6 orang peserta didik melalui angket respon peserta didik. Dari hasil analisis data uji validasi diperoleh rata-rata persentase skor untuk: (1) silabus 88,77\%; (2) RPP 90,60\%; (3) LKPD 91,98\%; (4) TKPM 94,89\%, masing-masing memenuhi kriteria sangat valid. Dan hasil analisis data uji kepraktisan diperoleh rata-rata persentase skor untuk respon peserta didik $87,46 \%$ dengan kriteria sangat praktis.
\end{abstract}

Kata kunci: Perangkat Pembelajaran, Model Pembelajaran Berbasis Masalah, Pemahaman Matematis

\section{PENDAHULUAN}

Semakin berkembang ilmu pengetahuan dan teknologi, konsep matematika semakin banyak digunakan, sehingga keterkaitan matematika dengan pengetahuan lainnya semakin jelas. Salah satu tujaun pembelajaran matematika menurut Permendikbud nomor 59 tentang kurikulum 2013 (Depdikbud, 2014), adalah agar peserta didik memiliki kemampuan pemahaman konsep matematika, mempunyai kompetensi dalam menjelaskan keterkaitan antar konsep dan mengaplikasikan konsep atau algoritma secara luwes, akurat, efisien, dan tepat dalam pemecahan masalah. Menurut kurikulum 2013 salah satu tujuan dari pembelajaran matematika di sekolah adalah untuk mengembangkan 
kemampuan-kemampuan yang dimiliki peserta didik, salah satunya yaitu memiliki kemampuan pemahaman matematis. Dalam penelitain Dian Novitasari (2016) menyebutkan bahwa kemampuan pemahaman matematis adalah salah satu tujuan penting dalam pembelajaran matematika, materimateri yang diajarkan kepada siswa bukan hanya sebagai hapalan, melainkan untuk dipahami agar siswa dapat lebih mengerti konsep materi yang diberikan, matematika merupakan mata pelajaran yang terdiri dari materi-materi yang saling berkaitan satu sama lain, sehingga untuk mempelajari suatu materi dibutuhkan pemahaman mengenai materi sebelumnya atau materi prasyarat. National Council Teachers of Mathematics dalam Rezkiyana Hikmah (2017), juga menyebutkan bahwa aspek yang sangat penting dalam prinsip pembelajaran matematika adalah kemampuan pemahaman matematika.

Dahlan (2011) menyatakan bahwa derajat pemahaman matematis ditentukan oleh keterkaitan suatu gagasan, prosedur atau fakta matematika yang akan dipahami secara menyeluruh jika memliliki jaringan yang kuat dan banyak. Pemahaman matematis menurut Skemp dalam Sumarmo (2013) terdi dari pemahaman instrumental dan pemahaman relasional. Pemahaman instrumental peserta didik hanya hafal sesuatu secara terpisah, menerapkan konsep pada perhitungan rutin/sederhana, mengerjakan konsep hanya secara algoritma saja. Sedangkan pemahaman relasional mengarahkan peserta didik untuk mengaitkan sesuatu dengan hal lainnya secara benar dan menyadari proses yang dilakukaannya. Indikator pemahaman matematis yang digunakan pada penelitian ini adalah : (1) mengembangkan syarat perlu atau syarat cukup suatu konsep; (2) menerapkan konsep secara algoritma; (3) menyajikan konsep dalam bentuk representasi matematika. Pentingnya kemampuan pemahaman matematis menurut Sumarmo (2013) karena diperlukan untuk menyelesaikan masalah matematika, masalah dalam disiplin ilmu lain dan masalah dalam kehidupan sehari-hari, yang merupakan visi pengembangan pembelajaran matematika untuk memenuhi masalah terkini. Namun pada kenyataannya justru kemampuan pemahaman matematis saat ini tergolong rendah. Sesuai dengan hasil penelitian (Suraji, Maimunah, \& Sehata Saragih, 2018), (Nuraeni, Evon Siti Mulyati, Rippi Maya, 2018), menemukan bahwa kemampuan pemahaman matematis peserta didik masih tergolong rendah. Hal berbeda dari hasil penelitian (Eka Liana Resta, Munawaroh, 2018) menyatakan bahwa kemampuan pemahaman matematis peserta didik tergolong sedang. Sedangkan hasil penelitian Apriliyanto (2019) menyebutkan bahwa kemampuan pemecahan masalah peserta didik masih rendah pada materi aplikasi turunan. Jika kemampuan pemecahan masalah matematis rendah, maka kemampuan pemahaman matematis juga rendah. Ratna Sariningsih (2014) mengatakan bahwa kemampuan pemahaman matematis (KPM) merupakan prasyarat seseorang untuk memiliki kemampuan pemecahan masalah matematis (KPMM).

Uraian di atas, memperlihatkan bahwa kemampuan pemahaman matematis perlu mendapat perhatian untuk ditingkatkan. Peningkatan kemampuan pemahaman matematis peserta didik dapat dilakukan oleh guru antara lain dengan cara : (1) guru memberi kesempatan kepada peserta didik untuk dapat mengemukakan ide-ide dan gagasannya; (2) guru merancang pembelajaran matematika melalui permasalahan yang memungkinkan peserta didik untuk dapat mamahami masalah matematis 
dengan baik; (3) guru merencanakan pembelajaran yang bermutu dan memilih model pembelajaran yang sesuai dengan karakteristik peserta didik yang diajarnya.

Salah satu model pembelajaran yang orientasinya pada permasalahan matematis adalah model pembelajaran berbasis masalah (PBM). Model pembelajaran Berbasis Masalah atau Problem Based Learning (PBL) menurut Aris Shoimin (2014) adalah sistem pengajaran yang mengembangkan secara stimulan strategi pemecahan masalah dan dasar-dasar pengetahuan dan keterampilan dengan menempatkan para peserta didik dalam peran aktif sebagai pemecah permasalahan sehari-hari yang tidak terstruktur dengan baik. Sedangkan menurut Komalasari (2013), model pembelajaran berbasis masalah adalah model pembelajaran yang menggunakan masalah dunia nyata sebagai suatu konteks bagi peserta didik utuk belajar tentang berfikir kritis dan keterampilan pemecahan masalah, serta untuk memperoleh pengetahuan dan konsep yang esensi dari mata pelajaran. PBM sesuai dengan filosofi konstruktivisme yaitu peserta didik diberi kesempatan lebih banyak untuk aktif mencari dan memproses informasi sendiri, membangun pengetahuan sendiri, dan membangun makna berdasarkan pengalaman yang diperolehnya (Sudewi, 2014). Langkah-langkah PBM menurut Kemendikbud (2017) adalah sebagai berikut : (1) orientasi peserta didik pada masalah; (2) mengorganisasikan peserta didik untuk belajar; (3) membimbing pengalaman individual atau kelompok; (4) mengembangkan dan menyajikan hasil karya; dan (5) menganalisis dan mengevaluasi proses pemecahan masalah. Pembelajaran berbasis masalah memungkinkan dapat memfasilitasi peningkatan kemampuan pemahaman matematis peserta didik. Menurut Marhamah Saleh (2013), Pembelajaran Berbasis Masalah (PBM) adalah suatu model pembelajaran yang didasarkan pada prinsip menggunakan masalah sebagai titik awal akuisisi dan integrasi pengetahuan baru.

Penelitian Usman Aripin (2015) menyimpulkan, peningkatan pemahaman matematis yang pembelajarannya menggunakan pendekatan pembelajaran berbasis masalah lebih baik dari pada yang pembelajarannya menggunakan pendekatan konvensional. Sumartini (2016), untuk meningkatkan kemampuan pemecahan masalah peserta didik, perlu didukung oleh model pembelajaran berbasis masalah. (Yelvalinda, Heni Pujiastuti, Abdul Fatah, 2019) menyatakan, model pembelajaran berbasis masalah memberikan konstruksi yang baik dalam mengembangkan kemampuan pemahaman matematis peserta didik. Pembelajaran berbasis masalah memberikan pengaruh lebih baik terhadap kemampuan pemahaman matematis peserta didik (Minarni, 2013). (Nurul Fitri, Said Munzi, M. Duskri, 2017) menyatakan model pembelajaran berbasis masalah dapat meningkatkan kemampuan repsentasi matematis peserta didik. (Erna Novianti, Putri Yuanita, Maimunah, 2020), penerapan model PBL meningkatkan kemampuan pemecahan masalah matematis peseta didik. (Desi Irawati, Nahor Murani Hutapea, Maimunah, 2020), menyatakan penerapan model Problem Based Learning (PBL) dapat memperbaiki proses pembelajaran dan meningkatkan hasil belajar matematika.

Dalam menggunakan model pembelajaran berbasis masalah, guru harus mampu membuat suatu perencanaan pembelajaran yang baik, sehingga pelaksanaan proses pembelajaran menjadikan peserta didik sebagai sentral dalam pembelajaran. Usman Aripin (2015) menyebutkan, dalam 
pembelajaran berbasis masalah, guru bertidak sebagai fasilitator pembelajaran artinya yang lebih banyak beperan adalah peserta didik. Guru membantu mengarahkan peserta didik untuk melakukan penemuan solusi permasalahan. Implikasinya peserta didik dituntut untuk belajar mandiri dalam menyelesaikan masalah yang ada, dengan bekerja sama mencari informasi dan menganalisis permasalahan untuk menemukan solusinya. Namun pada kenyataannya tidak jarang dijumpai bahwa dalam proses pembelajaran yang berperan lebih aktif adalah guru, sedangkan peserta didik hanya sekedar menerima informasi dan kurang berperan aktif (Abdur.A.A.Q, Firdaus, 2016). Kebanyakan peserta didik terpaku menjadi penonton sementara arena kelas dikuasai hanya segelintir orang. Suasana kelas perlu direncanakan dan dibangun sedemikian rupa sehingga peserta didik mendapat kesempatan untuk berinteraksi satu sama lain.

Rancangan pembelajaran dapat dituangkan dalam bentuk perangkat pembelajaran berupa silabus, Rencana Pelaksanaan Pembelajaran (RPP), Lembar Kerja Peserta Didik (LKPD), dan Tes Kemampuan Pemahaman Matematis (TKPM). Menurut Trianto (2011), Perangkat pembelajaran merupakam komponen perangkat yang digunakan dalam mengelola proses pembelajaran untuk mencapai kompetensi yang ingin secara maksimal. Perangkat pembelajaran merupakan sejumlah bahan, alat, media, petunjuk dan pedoman yang digunakan dalam proses pembelajaran di kelas. Silabus adalah bagian utama dalam perangkat pebelajaran yang dususun memuat kompetensi inti, kompetensi dasar, materi pokok/ pembelajaran, indikator, kegiatan pembelajaran, penilaian, alokasi waktu, dan sumber belajar. Guru harus berinovasi dalam mengembangkan kompetensi profesionalnya untuk menciptakan proses pembelajaran yang bermutu.

Mengingat pentingnya kemampuan pemahaman matematis, peneliti melakukan observasi terhadap guru matematika di SMA Negeri 2 Tambang Kabupaten Kampar melalui wawancara dan diskusi dengan guru matematika di sekolah tersebut. Dari hasil observasi, diperoleh informasi diantaranya adalah : (1) Kemampuan pemahaman matematis peserta didik rendah; (2) motivasi belajar peserta didik kurang; (3) Perangkat pembelajaran yang digunakan guru kurang baik karena perangkat yang digunakan belum pernah diuji kevalidan dan kepraktisannya; (4) Penerapan model-model pembelajaran kurang maksimal; (5) Sarana pembelajaran yang digunakan guru dalam setiap pelaksanaan proses pembelajaran kurang mendukung proses pembelajaran, (6) soal-soal yang dijadikan sebagai alat evaluasi cenderung tidak kontekstual dan tidak berbasis masalah.

Berdasarkan masalah diatas, peneliti termotivasi untuk melakukan penelitian yaitu Pengembangan Perangkat Pembelajaran Matematika Menggunakan Pembelajaran Berbasis Masalah untuk Memfasilitasi Kemampuan Pemahaman Matematis Peserta Didik Kelas XI SMA pada materi Aplikasi turunan. Perangkat pembelajaran yang dikembangkan berupa Silabus, Rencana Pelaksanaan Pembelajara (RPP), Lembar Kerja Peserta Didik (LKPD) dan Tes Kemampuan Pemahaman Matematis (TKPM). Rumusan masalahnya adalah bagaimana proses dan hasil pengembangan produk perangkat pembelajaran matematika menggunakan pembelakaran berbasis masalah untuk memfasilitasi kemampuan pemahaman matematis peserta didik kelas XI SMA pada materi aplikasi 
turunan yang memenuhi kriteria valid dan praktis?. Penelitian ii bertujuan untuk menghasilkan perangkat pembelajaran matematika menggunakan pembelajaran berbasis masalah untuk memfasilitasi kemampuan pemahaman matematis peserta didik kelas XI SMA pada materi aplikasi turunan berupa silabus, RPP, LKPD, dan tes kemampuan pemehaman matematis (TKPM) yang memiliki kualitifikasi valid dan praktis

Silabus adalah pedoman dalam penyusunan Rencana Pelaksanaan Pembelajaran (RPP). RPP adalah rencana kegiatan pembelajaran tatap muka untuk satu pertemuan atau lebih yang dikembangkan dari silabus untuk mengarahkan kegiatan pembelajaran peserta didik dalam upaya mencapai Kompetensi Dasar (KD) yang disusun secara lengkap dan sistematis agar pembelajaran berlangsung secara interaktif, inspiratif, menyenangkan, menantang, efisien, memotivasi peserta didik untuk berpartisipasi aktif, serta memberikan ruang yang cukup bagi prakarsa, kreativitas, dan kemandirian sesuai dengan bakat, minat, dan perkembangan fisik serta psikologis peserta didik (Kemendikbud, 2016). Lembar Kerja Peserta Didik (LKPD) adalah sarana untuk mempermudah interaksi guru dan peserta didik yang merupakan lembaran berisikan tugas-tugas yang harus dikerjakan pesertadidik. Suatu LKPD memuat judul, tujuan pembelakaran, petumju penggunaan, langkah-langkah berupa pertanyaan yang membimbing, dan penilaian. Prastowo (2015) LKPD adalah bahan ajar cetak yang berisi lembaran-lembaran yang berisi materi, ringkasan dan petunjuk yang harus dilaksanakan oleh peserta didik. Tes Pemahaman Matematis (TPM) dimkasudkan dalam penelitian adalah instrume tes pemahaman matematis sebagai alat ukur kemampuan pemahaman matematis peserta didik bagi pengguna hasil produk yang dikembangankan ini. Instrumen ini sekaligus berfungsi sebagai ulangan harian pada materi aplikasi turunan. TPM terdiri dari kisi-kisi soal, lembaran soal, pedoman penskoran, dan rubrik penilaian.

\section{METODE}

Metode pengembangan yang digunakan adalah model 4D yang dirancang oleh Silvasailam Thiagaradjan, Dorothy S. Semmel, dan Melvyn I. Semmel dalam Endang (2014), yaitu define, design, develop, dan disseminate namun dilaksanakan hanya sampai develop. Prosedur pengembangan mengikuti langkah-langkah diagram alur seperti Gambar 1. Penelitian ini dilakukan di SMA Negeri 2 Tambang Kabupaten Kampar Tahun Pelajaran 2019/2020 pada semester genap kelas XI IPA2 .

Tahap awal (Define) yang dilakukan yaitu melakukan observasi dan diskusi dengan guru matematika SMA Negeri 2 Tambang untuk menetapkan masalah dasar yang dihadapi, solusi dari permasalahan, dan mengetahui karakteristik peserta didik kelas XI IPA2. Selanjutnya dilakukan analisis KD dan indikator pencapaian kompetensi, analisis materi pokok/ materi pembelajaran, dan merumuskan tujuan pembelajaran. Kemudian pada tahap kedua (design) peneliti mengumpulkan referensi, merancang perangkat pembelajaran, merancang lembar validasi dan angket respon peserta didik. Pada tahap akhir yaitu development peneliti mengembangkan perangkat pembelajaran sesuai 
dengan rancangan awal, validasi dan revisi produk, serta uji coba terbatas. Perangkat divalidasi oleh validator yang terdiri dari dua orang ahli (dosen pendidikan matematika) dan seorang praktisi (guru matematika SMA) dengan menggunakan lembar validasi.

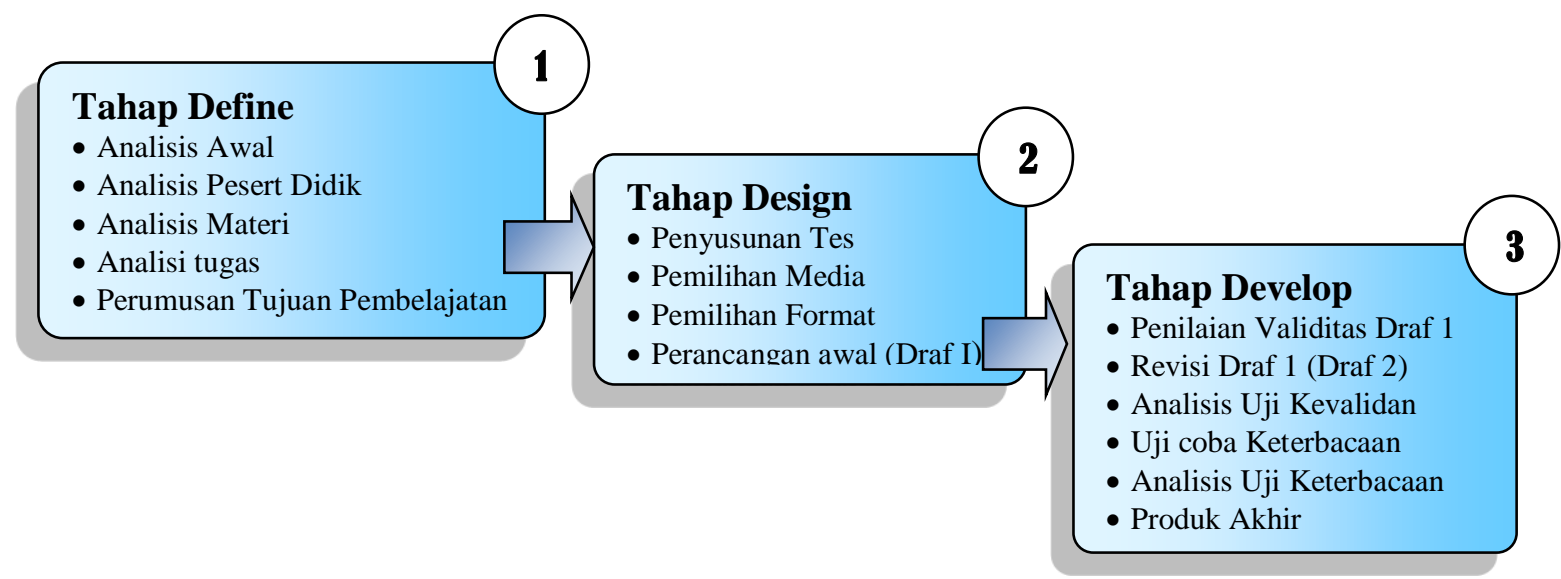

Gambar 1. Prosedur Penelitian

Hasil validasi kemudian dianalisis dan direvisi sesuai dengan saran validator. Setelah dilakukan revisi, Draf perangkat pembelajaran matematika berupa LKPD diujicobakan pada kelompok kecil. Uji coba dilakukan di SMA Negeri 2 Tambang pada tanggal 1, 2 dan 3 Juni 2020 dengan memilih 6 orang peserta didik kelas XI IPA2. Setelah LKPD diujicobakan, peneliti memberikan angket respon siswa untuk memperoleh data respon siswa terhadap penggunaan LKPD matematika berbasis masalah pada materi Aplikasi Turunan kelas XI SMA.

Teknik analisis data pada penelitian ini adalah teknik analisis data kuantitatif yang terdiri dari analisis data hasil validasi oleh validator dan analisis data hasil angket respon. Penilaian validator menggunakan skala Likert dengan 5 skala. Untuk penilaian validator 1, 2, 3, 4 dan 5 yang menyatakan sangat tidak baik, kurang baik, cukup baik, baik, dan sangat baik. Dan angket respon peserta didik menggunakan skala Likert dengan pernyataan positif dan negatif. Untuk pernyataan positif skor 1, 2, 3, 4, dan 5 yang menyatakan sangat tidak setuju, tidak setuju, kurang setuju, setuju, dan sangat setuju dan pernyataan negatif skor 5, 4, 3, 2, dan 1 yang menyatakan sangat tidak setuju, tidak setuju, kurang setuju, setuju, dan sangat setuju. Skor hasil validasi silabus, RPP, LKPD, TPM, dan hasil angket respon peserta didik dinyatakan dalam persentase skor yang diberikan oleh validator/responden, dengan rumus :

$V_{a}=\frac{T s a}{T s h} X 100 \%$

Keterangan:

$V_{a}=$ Persentase skor tiap validator/responden

$T s a=$ skor dari tiap validator/responden

$T s h=$ total skor maksimal yang diharapkan 
Selanjutnya dihitung persentase rata-rata total dengan rumus :

$P=\frac{\sum V_{a}}{n}$

Keterangan :

$\mathrm{P}=$ Persentase rata-rata total tiap perangkat

$\mathrm{n}$ = banyak validator/responden

$V_{a}=$ Persentase skor tiap validator/responden

Kevalidan perangkat pemelajaran (silabus, RPP, LKPD, TKPM) dan Kepraktisan LKPD ditentukan oleh kriteria kevalidan dan kepraktisan berdasarka Tabel 1.

\section{Tabel 1.}

Kriteria Kevalidan dan Kepraktisan

\begin{tabular}{|c|c|c|}
\hline \multirow{2}{*}{$\begin{array}{c}\text { Persentase } \\
\text { rata-rata total }\end{array}$} & \multicolumn{2}{|c|}{ Kriteria } \\
\cline { 2 - 3 } & Kevalidan & Kepraktisan \\
\hline $80 \%<P \leq 100 \%$ & Sangat Valid & Sangat Praktis \\
\hline $60 \%<P \leq 80 \%$ & Valid & Praktis \\
\hline $40 \%<P \leq 60 \%$ & Cukup Valid & Cukup Praktis \\
\hline $20 \%<P \leq 40 \%$ & Kurang Valid & Kurang Praktis \\
\hline $0 \%<P \leq 20 \%$ & Tidak Valid & Tidak Praktis \\
\hline
\end{tabular}

Sumber: diadabtasi dari Akdon, Riduwan (2013)

Perangkat pembelajaran (silabus, RPP, LKPD, TPM) dikatakan valid jika memenui kriteria minimal valid. Dan LKPD dikatakan praktis jika memenuhi kriteria minimal Praktis. Kevalidan perangkat pembelajaran adalah kriteria kualitas perangkat pembelajaran (Silabus, RPP, LKPD, dan TKPM). Menurut Alwi (2011), valid adalah menurut cara yang semestinya, sesuai dengan semestinya; berlaku; sahih. Untuk mendapatkan suatu produk baru yang sahih dan layak, dilakukan validasi terhadap rancangan produuk yang dikembangkan kepada para ahli dibudang produk uang dikembangkan. Sesuai dengan Putra (2011) menyatakan, validasi adalah proses menilai apakah produk baru secara rasional lebih baik dan efektif dengan cara meminta penilaian ahli yang berpengalaman. Nieveen dalam Rochmad (2012), mengemukakan bahwa kevalidan suatu perangkat pembelajaran dapat merujuk pada dua hal, yaitu (1) apakah kurikulum atau perangkat yang dikembangkan didasarkan pada rasional teoretik yang kuat, dan (2) apakah terdapat konsistensi secara internal. Diperkuat oleh Sa'adun Akbar (2013) mengatakan, bahwa validasi terhadap perangkat pembelajaran dilakukan dengan cara seseorang atau beberapa ahli pembelajaran memberikan penilaian terhadap perangkat pembelajaran melalui instrumen validasi ahli untuk menilai kesesuaian perangkat pembelajaran dengan teorinya dan memberi masukan untuk perbaikan perangkat pembelajaran, Sejalan dengan itu Rochmad (2012), juga mengemukakan bahwa validitas perangkat pembelajaran adalah dikatakan valid apabila perangkat pembelajaran dinyatakan layak digunakan dengan revisi atau tanpa revisi oleh validator. Kevalidan perangkat pembelajaran yang dikembangkan dinilai dari aspek validasi isi dan validasi kunstuksi. Validasi isi merupakan penilai terkait isi atau muatan materi pada perangkat pembelajaran yang dikembangkan. Sedangkan aspek validasi Kunstruksi adalah penilaian perangkat 
pembelajaran berdasatkan teroritis yang kuat. Perangkat pembelajaran yang dikembangkan dinyatakan valid jika persentase rata-rata masing-masing validator memenuhi kriteria minimal Valid.

Kepraktisan adalah suatu kemudahan dalam penggunaan sesuatu sehingga dalam pekaiannya praktis dan tidak menyulitkan. Menurut Windrianto, Rusdi, Syafdi Maizora (2017), mengemukakan bahwa praktis jika pengguna tidak kesulitan dari segi penyajian materi maupun penggunaan materi pembelajaran. Sementara itu menurut Alwi (2011) praktis adalah berdasarkan praktik; mudah dan senang memakainya. Kepraktisan yang dimaksud disini adalah kepraktisan perangkat pembelajaran. Kepraktisan perangkat pembelajaran adalah kepraktisan penggunaan perangkat pembelajaran oleh pengguna. Tingkat kepraktisan perangkat pembelajaran dapat diketahui setelah perangkat pembelajaran tersebut digunakan dalam pembelajaran. Menurut Nieveen dalam Rochmad (2012) mengemukakan bahwa kepraktisan suatu perangkat pembelajaran yang dikembangkan dapat dilihat dari tingkat kemudahan dan keterbantuan dalam penggunaannya. Sejalan dengan pendapat Sa'dun Akbar (2013), bahwa dalam menggunakan perangkat pembelajaran pengguna mengetahui dan merasakan tingkat kepraktisan perangkat pembelajaran. Kepraktisan harus memenuhi kebutuhan pengguna.

Kepraktisan dalam penelitian ini adalah kepraktisan penggunaan perangkat pembelajaran matematika menggunakan pembelajaran berbasis masalah untuk memfasilitasi kemampuan pemahaman matematis peserta didik kelas XI SMA pada materi aplikasi turunan yang praktis menurut pengguna perangkat pembelajaran. Tingkat kepraktisan perangkat pembelajaran ditentukan dengan kriteria kepraktisan. Kepraktisan perangkat pembelajaran dilakukan dengan beberapa kali uji coba baik uji coba kelompok kecil, uji coba kelompok besar ataupun uji coba diperluas. Pada penelitian ini kepraktisan perangkat pembelajaran adalah kepraktisan Lembar Kerja Peserta Didik (LKPD) melalui uji coba keterbacaan oleh peserta didik melalui uji coba kelmpok kecil. Kepraktisan dapat dicapai jika penilai kepraktisan oleh peserta didik memenuhi krikteia minimal praktis.

\section{HASIL}

Hasil penelitian yang diharapkan adalah perangkat pembelajaran matematika menggunakan pembelajaran berbasis masalah untuk memfasilitasi pemahaman matematis peserta didik kelas XI SMA yang valid dan praktis. Berdasarkan proses yang dilakukan menurut prosedur yang ditetapkan dan setelah dilakukan analisis data diperoleh hasil sebagai berikut :

\section{Kevalidan Perangkat Pembelajaran}

a. Kevalidan silabus dinilai dari 8 aspek, yaitu kesesuaian identitas, ketepatan $\mathrm{KI} / \mathrm{KD}$, materi pokok, indikator pencapaian kompetensi (IPK), kegiatan pembelajaran, penilaian, alokasi waktu, dan sumber belajar. Hasil penilaian validitas terhadap semua aspek silabus yang dinilai oleh ketiga validator ditunjukkan pada Gambar berikut.

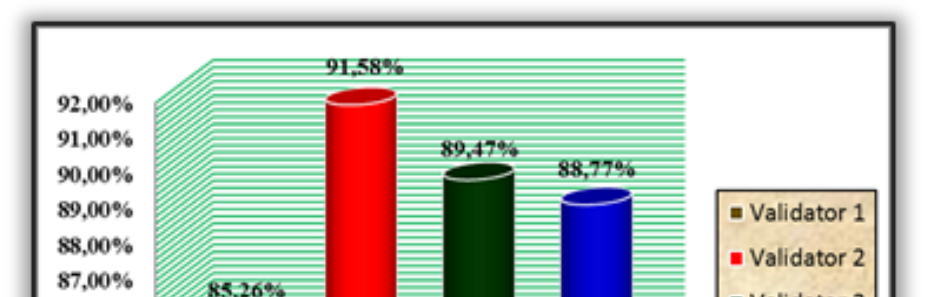




\section{Gambar 2. Rata-rata skor kevalidan Silabus}

Dari data pada gambar 2 menunjukkan bahwa perangkat pembelajaran yang dikembangkan telah menghasilkan silabus yang sangat valid, karena Skor penilaian masing-masing validator terhadap silabus dan rata-rata skor penilaian kevalidan silabus telah memenuhi kriteria kevalidan yaitu berada pada interval $80 \%<P \leq 100 \%$.

b. RPP yang yang divalidasi sebanyak 6 RPP, kevalidan RPP dinilai dari 7 aspek, yaitu; (1) Identitas RPP; (2) Indikator dan Tujuan Pembelajaran; (3) Materi Pembelajaran; (4) Model Pembelajaran, Pendekatan, dan Metode Pembelajaran; (5) Pemilihan sumber belajar/media pembelajaran; (6) Langkah-Langkap Pembelajaran; dan (7) Penilaian Hasil Belajar. Hasil analisis data kevalidan RPP ditunjukkan pada Gambar. 3.

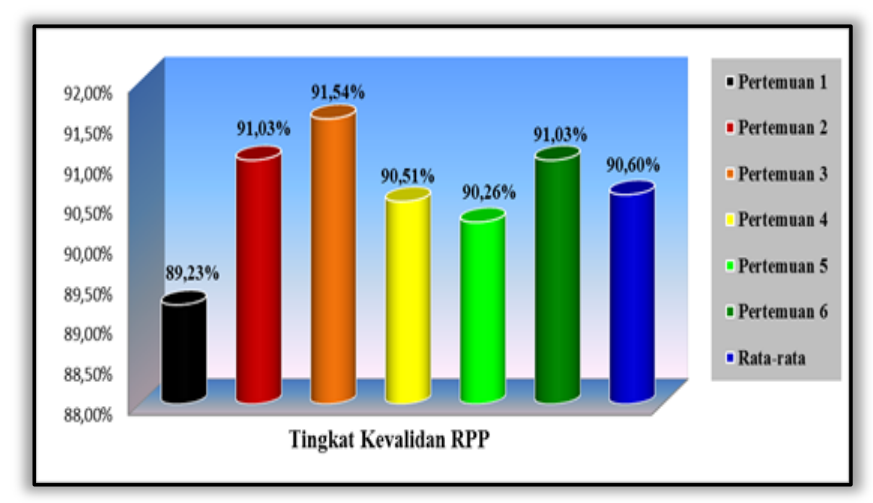

Gambar 3. Rata-rata skor kevalidan RPP

Dari data pada gambar diatas menunjukkan bahwa perangkat pembelajaran yang dikembangkan telah menghasilkan RPP yang sangat valid, karena skor kevalidan RPP setiap pertemuan, dan ratarata skor untuk penilaian semua RPP telah memenuhi kriteria kevalidan yaitu berada dalam interval $80 \%<P \leq 100 \%$

c. LKPD yang divalidasi sebanyak 6 LKPD, kevalidan LKPD dinilai berdasarkan landasan teoritik yang kuat, dan komponen-komponen LKPD yang saling berkaitan. Kevalidan RPP dinilai dari 5 aspek, yaitu; (1) Kelayakan isi; (2) Kesesuaian Penyajian dengan Pendekatan Pembelajaran; (3) Kesesuaian dengan syarat Didaktis; (4) Kesesuaian dengan syarat konstruksi (Kebahasaan); dan 
(5) Kesesuaian dengan syarat teknis (Kegrafikan). Hasil analisis data kevalidan LKPD ditunjukkan pada Gambar 4.

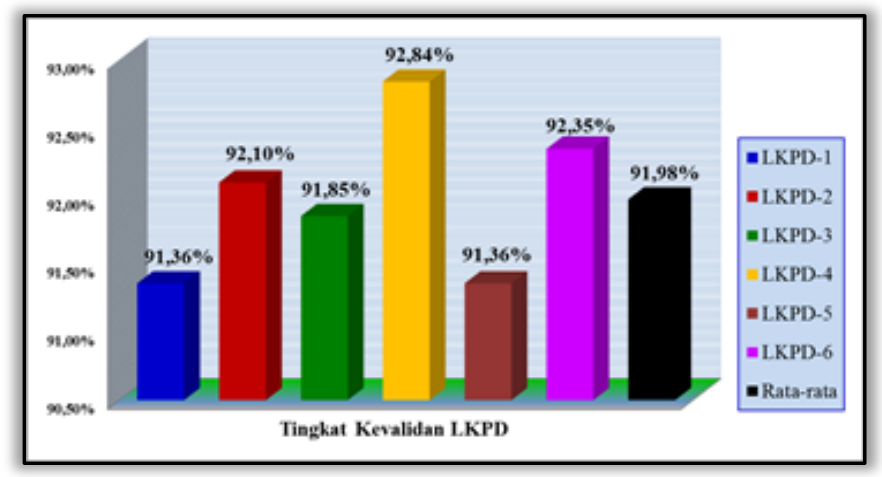

Gambar 4. Rata-rata skor kevalidan LKPD

Dari data pada gambar 4 diatas menunjukkan bahwa perangkat pembelajaran yang dikembangkan telah menghasilkan LKPD yang sangat valid, karena skor penilaian masing-masing LKPD dan rata-rata skor kevalidan LKPD secara keseluruhan telah memenuhi kriteria kevalidan yaitu berada dalam interval $\quad 80 \%<P \leq 100 \%$.

d. Kevalidan TKPM dinilai dari tiga aspek, yaitu; (1) Kesesuaian soal dengan indikator dan Tujuan Pembelajaran; (2) Kesesuaian dengan Pembelajaran Berbasis Masalah; (3) Kesuaian Bahasa dan kaidah penulisan soal. Hasil analis data kevalidan TKPM ditunjukkan pada Gambar berikut.

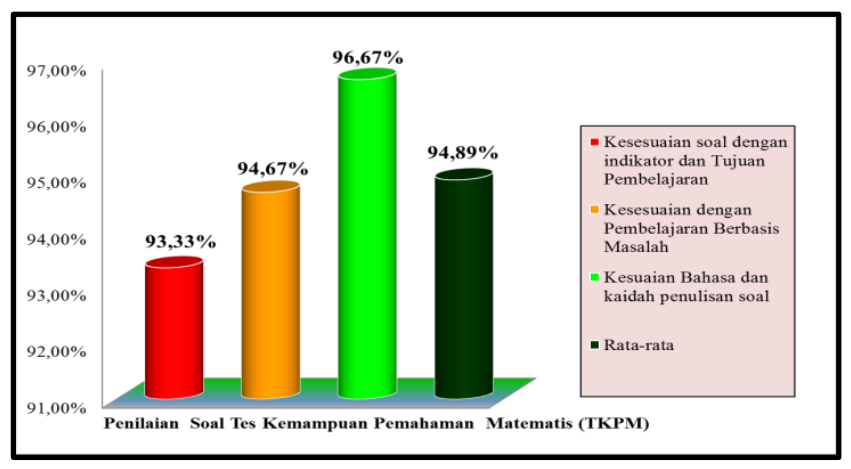

Gambar 5 Rata-rata skor kevalidan TKPM

Dari data pada gambar diatas menunjukkan bahwa perangkat pembelajaran yang dikembangkan telah memiliki tes kemampuan pemahaman matematis (TKPM) yang sangat valid, karena skor setiap aspek penilaian TKPM, dan rata-rata penilaian semua aspek TKPM telah memenuhi kriteria kevalidan yaitu berada dalam interval $80 \%<P \leq 100 \%$.

\section{Kepraktisan perangkat pembelajaran,}

Kepraktisan perangkat pembelajaran dalam penelitian ini hanya terbatas pada kepraktisan LKPD melalui uji keterbacaan pada kelompok kecil. Sedangkan uji keterlaksanaan pembelajaran tidak dilakukan karena situasional wabah Covid-19. LKPD yang diujikan pada uji keterbacaan sebanyan 6 LKPD, Aspek yang dinilai yaitu; (1) Kesesuaian penggunaan bahasa dan kalimat serta tampilan 
LKPD; (2) Penggunaan LKPD dalam pembelajaran; (3) Materi LKPD; dan (4) Model Pembelajaran Berbasis Masalah. Hasil analisi data kepraktisan seperti ditunjukkan Gambar berikut.

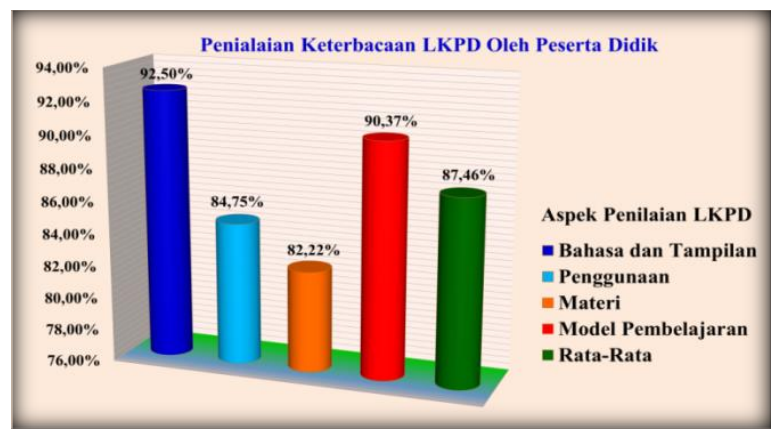

Gambar 5. Rata-rata skor kepraktisan LKPD

Dari data pada gambar 5 menunjukkan bahwa Perangkat pembelajaran yang dikembangkan telah menghasilkan LKPD yang sangat praktis, karena skor penilaian setiap aspek LKPD dan rata-rata secara keseluruhan aspek LKPD telah memenuhi kriteria kepraktisan yaitu berada dalam interval $80 \%<P \leq 100 \%$

\section{KESIMPULAN}

Berdasarkan proses dan hasil penelitian yang telah dilakukan, dapat ditarik kesimpulan bahwa produk akhir penelitian pengembangan ini menghasilkan perangkat pembelajaran matematika menggunakan pembelajaran berbasis masalah pada materi aplikasi turunan yang sangat valid dan sangat praktis dan dapat digunakan untuk memfasiltasi kemampuan pemahaman matematis peserta didik kelas XI SMA. Perangkat pembelajaran yang dihasilkan perlu dilanjutkan pada uji lapangan untuk mengetahui tingkat efektifitas produk ini.

\section{DAFTAR PUSTAKA}

Abdur.A.A.Q, Firdaus. (2016). Meningkatkan Kemampuan Berpikir Kreatif Matematis Peserta didik SMA Melalui Pembelajaran Open Ended pada Materi SPLDV, Jurnal Pendidikan 1(2) : 227236.

Akdon, dan Riduwan. (2013). Rumus dan Data Dalam Analisis Statistika, Bandung, Alfabeta.

Alwi, Hasan. (2011). Kamus besar bahasa Indonesia, Gramedia Pustaka Utama, Jakarta

Apriliyanto, B. (2019). Analisis kesalahan peserta didik dalam pemecahan masalah turunan fungsi aljabar. Jurnal Komunikasi Pendidikan, 3(2), 117-125

Aris Shoimin. (2014). Model pembelajaran inovatif dalam kurikulum 2013, AR-ruz media, Yokyakarta.

Dahlan, J. A. (2011). Analisis Kurikulum Matematika. Jakarta, Universitas Terbuka.

Desi Irawati, Nahor Murani Hutapea, Maimunah, (2020). Penerapan Model Problem Based Learning untuk Meningkatkan Hasil Belajar Matematika Peserta Didik Kelas VIII.4 SMP Negeri 8 Pekanbaru, Jurnal eduMATH, 9(2), 1-20.

Dian Novitasari.(2016). Pengaruh penggunaan multimedia interaktif terhadap kemampuan 
pemahaman konsep matematis siswa, Jurnal Pendidikan matematika \& matematika, Vol 2 No 2, Desember 2016, Universitas Muhammadiyah Tangerang, Banten

Eka Liana Resta, Munawaroh. (2018). Kemampuan pemahaman matematis siswa pada materi segi empat, Jurnal Pendidikan Tambusai, 2(6), 1710-1718.

Endang Purwoastuti. (2014). Metodologi Penelitian, PT Pustaka Baru, , Yogyakarta

Erna Novianti, Putri Yuanita, Maimunah.2020. Pembelajaran Berbasis Masalah dalam Meningkatkan Kemampuan Pemecahan Masalah Matematika, Journal of Education and Learning Mathematics Research (JELMaR), 1(1), 65-73.

Kemendikbud .(2016). Permendikbud Nomor 22 Tahun 2016 Tentang Standar Proses Pendidikan Dan Menengah, Kemendikbud, Jakarta

Kemendikbud. (2017). Model-model Pembelajaran, Jakarta, Direktoran Pembinaan SMA.

Komalasari, K. (2013). Pembelajaran Kontekstual Konsep dan Aplikasi, Bandung, PT Refika Aditama.

Marhamah, S. (2013). Strategi pembelajaran fiqh dengan Problem-Based Learning, Jurnal Ilmiah Didaktika, 12(1), 190-220.

Minarni, A. (2013). Pengaruh Pembelajaran Berbasis Masalah Terhadap Terhadap Kemampuan Pemahaman Matematis dan Keterampilan Sosial Peserta didik SMP Negeri di Kota Bandung, Paradikma Jurnal Pendidikan Matematika , 6(2), 162-174.

Nuraeni, Evon Siti Mulyati, Rippi Maya. (2018). Analisis kemampuan pemahaman matematis dan tingkat kepercayaan diri pada siswa MTs, dalam Jurnal Jurnal Pembelajaran Matematika Inovatif, Vol 1 No 5, September 2018, IKIP Siliwangi, Bandung

Nurul Fitri, Said Munzir, M. Duskri. (2017). Meningkatkan Kemampuan Representasi Matematis Melalui Penerap-an Model Problem Based Laraning, Jurnal Didaktik Matematika, 4(1), 59-67.

Permendikbud. (2014). Peraturan Menteri Pendidikan dan Kebudayaan Republik Indonesia Nomor 59 Tahun 2014 Tentang Kurikulum 2013 Sekolah Menengah Atas/ Madrasah Aliyah, Departemen Pendidikan dan Kebudayaan, Jakarta.

Prastowo, A. (2015). Panduan Kreatif Membuat Bahan Ajar Inovatif, Yogyakarta, Diva Press.

Putra, N. (2011). Research and development Penelitian dan pengembangan suatu pengantar, Rajagrafindo Persada, Jakarta

Ratna Sariningsih. 2014. Pendekatan kontekstual untuk meningkatkan kemampuan pemahaman matematis siswa SMP, dalam Jurnal Infinity, Vol 3 No 2, 150-163.

Rezkiyana Hikmah. 2017. Penerapan model advance organizer untuk meningkatkan kemampuan pemahaman pemahaman siswa, Jurnal SAP Vol. 1 No. 3 April 2017 Universitas Indraprasta PGRI, Jakarta.

Rochmad. 2012. Desain Model Pengembangan Perangkat Pembelajaran Matematika, Jurnal Kreano, Vol 3 No 1, Juni 2012, Jurusan Matematika FMIPA UNNES, Semarang

Sa'dun Akbar. 2013. Instrumen Perangkat Pembelajaran, Bandung, Remaja Rosda Karya.

Sudewi, N.L, dkk. 2014. Studi Komparasi Peng-gunaan Model Pembelajaran Problem Based Learning (PBL) dan Kooperatif Tipe Group Investigation (GI) Terhadap Hasil Belajar Berdasarkan Taksonomi Bloom, Journal Program Pascasarjana Universitas Pendidikan 
Ganesha. 4(1), 1-9.

Sumarmo, U. 2013. Berpikir dan Disposisi Matematik Serta Pembelajarannya. Kum-pulan Makalah, Bandung, FMIPA UPI.

Sumartini, T. S. 2016. Peningkatan Kemampuan Pemecahan Masalah Matematis Siswa melalui Pembelajaran Berbasis Masalah, Jurnal Jurnal Mosharafa, Vol 5 No 2, Mei 2016, STKIP Garut, Bandung

Suraji, Maimunah, Sehatta Saragih. 2018. Analisis Kemampuan Pemahaman Konsep Matematis dan Kemampuan Pemecahan Masalah Matematis Siswa SMP pada Materi Sistem Persamaan Linear Dua Variabel (SPLDV), Suska Journal of Mathematics Education, 4(1), 9 -16.

Trianto. 2011. Model Pembelajaran Terpadu Konsep,Strategi Dan Implementasinya Dalam Kurikulum Tingkat Satuan Pendidikan (KTSP), Jakarta, Bumi Aksara.

Usman, A. 2015. Meningkatkan Kemampuan Pemahaman Matematik Peserta didik SMP Melalui Pendekatan Pembelajaran Berbasis masalah, Jurnal P2M STKIP Siliwangi, 2(1), 120-127.

Windrianto, Rusdi, Syafdi Maizora. 2017. Efektifitas Lembar Kerja Siswa Dengan Model Problem Based Learning pada Materi Bangun Ruang Sisi Datar Kelas VIII SMP, dalam Jurnal Penelitian Pembelajaran Matematika Sekolah (JP2MS), Vol 1 No 2, Desember 2017, Program Studi Pendidikan Matematika JPMIPA FKIP Universitas Bengkulu, Bengkulu

Yelvalinda, Heni Pujiastuti, Abdul Fatah. (2019). Pengaruh Model Pembelajaran Problen Based Learning terhadap Kemampuan Pemahaman Matematis, Prosiding Seminar Nasional \& Call For PapersProgram Studi Magister Pendidikan MatematikaUniveritas Siliwangi, Tahun 2013, 633 640 